\title{
IKTIDARA UZANAN YOLDA EYYûBî AiLESININ SERÜVENi
}

\author{
Adventure of Ayyubid Family on the Way of Power
}

\section{Dr. Osman GüRBüZ*}

\begin{tabular}{|c|c|}
\hline ÖZ & ABSTRACT \\
\hline 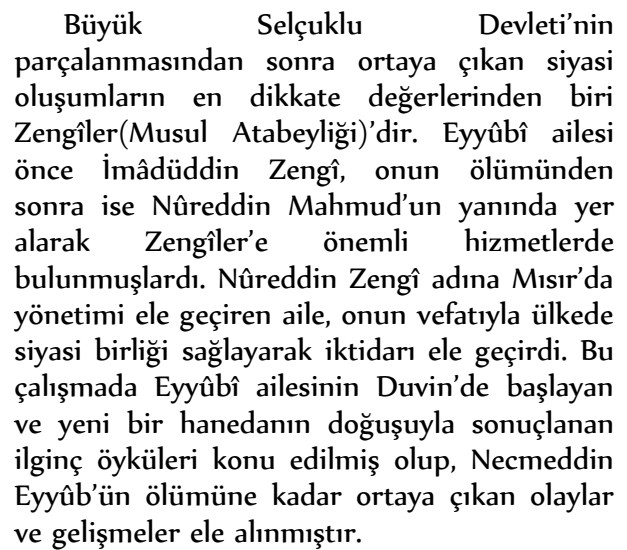 & $\begin{array}{l}\text { One of the most notable political } \\
\text { formations that emerged after the break up of } \\
\text { the Great Seljuk Empire is Zengid Dynasty } \\
\text { (Atabeg of Mosul). Ayyubid Family made } \\
\text { important services for Zengid Dynasty by } \\
\text { taking part near of Imad ad-Din Zengi firstly, } \\
\text { and after of their death, near of Nur ad-Din } \\
\text { Mahmud. The family that seized Egypt's } \\
\text { governance on behalf of the Nur ad-Din Zengi } \\
\text { captured the power by allowing political unity } \\
\text { in the country after death of him. In this } \\
\text { study, interesting story of Ayyubid Family that } \\
\text { begins at Duvin and resulting in the birth of a } \\
\text { new dynasty; events and developments until } \\
\text { Najm ad-Din Ayyup's death are discussed. }\end{array}$ \\
\hline
\end{tabular}

Anahtar Sözcükler: Eyyubî ailesi, Zengîler, İmadüddin Zengî, Nureddin Mahmud, iktidar.

Key Words: Ayyubids Family, Zengid Dynasty, Imad ad-Din Zengi, Nur ad-Din Zengi,Power.

\section{A. Eyyûbîler'in Kökleri}

Selâhaddin Eyyûbînnin babası Necmeddin Eyyûb, Duvin'de doğmuştu. (ibni Şeddâd 1994: 31) Tarihçiler doğum tarihi hakkında bilgi vermemekle birlikte onun yaklaşık Xl. Yüzyılın sonları ve XIl. Yüzyılın başlarında doğduğu tahmin edilmektedir. Duvin, Azerbaycan'ın Rum(Anadolu) sınırındaki son şehir ve kalesi olup Şeddâdîler'in yönetim merkezi idi. Günümüzde Ermenistan'ın başkenti Erivan'ın 50 kilometre güneyinde bir ören yeri olan şehir, lğdır ilimizin kuzeydoğusuna düşmekte olup, adı geçen şehre 50- 60 kilometrelik bir uzaklıkta bulunmaktadır. Eyyûb b. Şâdînin Duvin'in merkezinde değil, şehrin yanı başında Ecdenakan isimli ve ahalisinin tamamının Kürtlerden oluştuğu bir köyde

\footnotetext{
Atatürk Üniversitesi ilâhiyat Fakültesi i̇slâm Tarihi ve Sanatları Bölümü Öğretim Üyesi (ogurbuz@atauni.edu.tr)
} 
ikamet ettiği de söylenir. (ibni Hallikan 1977: 7/139) Selâhaddin'in son on yllında daima yanında bulunan ve onun hayatı hakkında değerli bir eser kaleme alan ibni Şeddâd (ibni Şeddâd 1994: 31), güvenilir tarihçi ỉbni'l-Esîr (ibni'l-Esîr 1963: 119) ve Halepli tarihçi ibni Ebî Tayy (Ebu Şâme 2002: 11/162-163), Necmeddin Eyyûb'un babasının Şadî olduğunu belirterek, Necmeddin Eyyûb b. Şadî üzerine başka hiçbir isim ilave etmezler. Bunun anlamı, Selâhaddin'in dedesi Şadînin dışındaki diğer ataları hakkında bilgimizin olmamasıdır.

Oysa Eyyûbîler Devleti'nin tarihini yazan ibni Vasıl, Selâhaddin'in ataları hakkındaki farklı görüşleri bize nakleder ve bu bilgilerin doğruluğu ve yanlışlı̆ı hakkında söylenenleri de aktararak konuyu daha iyi anlamamıza yardımcı olur. ibni Vasıl, Eyyûbî meliklerinin babası Necmeddin Eyyûb ve kardeşi Esedüddin Şîrkûh'un Şadî b. Mervan'ın oğulları olduğunu belirterek, bazılarının, Şadî b. Mervan b. Muhammed b. Yakub şeklinde soy ağacına üç yeni ata eklediğini söyler. (ibni Vâsıl 1957: 11/3) Eyyûbîler'in kökeni hakkında farklı görüşlerin bulunduğunu ifade ederek, Musullu tarihçi ibni'l-Esîr'in, Eyyûbîler'in asıllarının Hezbâniyye aşiretinin bir kolu olan Revvâdîye Kürtlerinden oldukları (ibni'l-Esîr 1963: 119) şeklindeki görüşüne yer verir. Ancak Eyyûbî meliklerinden bir kısmı, Kürtlere mensubiyetlerini kabul etmeyerek, kendilerinin Arap olduğunu, Kürtlerin memleketinde ikamet edip kendileriyle evlenmelerinden dolayı Kürt asıllı tanındıklarını söylerler. O meliklerden biri Selâhaddin'in kardeşinin oğlu elMelikü'l-Mu'izz ìsmail b. Seyfülislam Tuğtekin idi.' Babası Seyfülislam Tuğtekin'den sonra Yemen yönetimini üstlenen ìsmail, el- Mu'izz Lidinillah ismiyle Yemende kendisini halife ilan etmişti. İbni Ebî Tayy ise İsmail'in Himar diye çağrılan son Emevî Halifesi Muhammed el Ca'dînin soyundan geldiğini iddia ederek, bununla hilâfeti Haşimilerden alarak yeniden Emevîler'e iade etmek istediğini ve bu suretle kendi halifelik emellerine kavuşmak arzusunda olduğunu, söyler. Ibni Ebî Tayy, sözlerine devamla bu haberin peşine düşüp iyice araştırdığını; fakat Eyyûbî ailesinden bir topluluğun ittifakla bu iddiayı yalanladıklarını ve aileden hiçbirinin Şadîden ileri bir ata tanımadıklarını ifade ettiklerini, belirtir. (Ebû Şame 2002: 11/163) Ebû Şâme ise Halepli tarihçinin sözlerinin doğru olduğunu onaylar ve başından geçen bir hatırasını zikrederek onun haklılı̆ııın altını çizer: “ Ben Dımaşk'ta bulunurken orada Necmeddin Eyyûb adına inşa edilen er-Ribâdü'n-Necmîye vakfedilen bir kitap görmüştüm. Kitabın üzerinde Necmüddin Ebû Saîd Eyyûb b. Şadî el-Adilî diye kayıt

\footnotetext{
'Eyyûbî ordusu Selâhaddin döneminin başlarında ( 569/1173) Yemen'i feth etmek için yola çıktı. Bu orduya Selâhaddin'in abisi Turanşah komuta etmekteydi. Turanşah Yemen'i fethettikten sonra ülkenin yönetimini üstlendi (569-577/1173-1181). Ondan sonra diğer kardeşi SeyfülislamTuğtekin yerine geçti (577-593/1181-1196). Onun ölümünden sonra da el Melikü'l -Mü'izz ìsmail (593598/1196-1201) yönetimi üstlendi
} 
düşülmüş, başkaca hiçbir şey ilave edilmemişti”. (Ebû Şame 2002: 11/164) Mezkûr iddiayı duyan Amcası Melik Adil, "Biz Benî Ümeyye soyundan değiliz, İsmail yalan söylemiş" diyerek iddiayı kabul etmemişti. (ibni Vâsıl 1957: 1/4) Bu iddia sahipleri şöyle bir nesep zinciri oluşturmuşlardı: “ Eyyûb b. Şadî b. Mervan b. Hakem b. Abdirrahman b. Muhammed b. Abdillah b. Muhammed b. Muhammed b. Abdirrahman b. Hakem b. Hişam b. Abdirrahman ed-Dâhil b. Muaviye b. Hişam b. Abdilmelik b. Mervan b. Hakem b. Ebi'l-'As b.ümeyye b. Abdi Şems b. Abdi Menaf'. Abdi Menafda Benî Ümeyye ve Hz. Peygamber (sav) in nesebi birleşiyordu.

Bir diğer grup ise neseplerini Benî Mürre b.'Avf ile irtibatlandırma yoluna gittiler. Bu nesep Melik Adil'in oğlu el-Melikü'l-Muazzam Şerafeddin i̇sa'ya getirilince onu dinleyip oğlu Selâhaddin Davud'a dinletti. (ibni Vâsıl 1957: 1/5) Aybek ed-Devadarî eserinde, aileden bazılarının asıllarının Kürt olduğunu kabul etmeyerek Arap olduklarını, Kürtlerin yanlarına inerek evlendiklerini ve bu suretle onlara karıştıklarını söyler. Bu iddiayı ileri süren kişinin yukarıda kendisinden söz edilen Ebu'l-Fida ìsmail b. Tuğtekin olduğunu belirtir; oysa bu söz amcası Melik Adil b. Eyyûb'un kulağına ulaştığında “Vallahi yalan söyledi, bizim aslımız Emevî değildir" dediğini kaydeder. (Ibni Vâsıl 1957: 1/4; edDevadârî 1972: VIII6)

Bu iddialardan kuşku duymamıza yol açan diğer bir husus ise, ìsmail b. Tuğtekin'in şahsiyeti ve yaşantısıdır. Gırtlağına kadar içki ve eğlenceye dalan İsmail, babasını kızdıran tutumlarından dolayı Hicaz'a sürgün edilir; Sirîn'de ikameti esnasında babasının ölüm haberi kendisine ulaştırılır; derhal Yemen'e döner ve yönetimin başına geçer. Yukarıda belirtildiği üzere Emevî soyundan geldiğini söyleyerek, kendisini halife ilan eder. Bu davranışlarından rahatsızlık duyan amcası Melik Adil, bir elçi vasıtasıyla böyle şeyler yapmaktan vazgeçmesini bildirerek kendisini ayıpladı. Hatta onun peygamberlik iddia ettiği söylenir. 599 yılında bir grup Kürt tarafından kafası kesilerek Zebîd şehrinde sokaklarda dolaştırıldı. ỉbni Hallikan ise, onun kureyşlilik iddiasına çok kızan amcasının, bunu insanları kendisine güldürecek bir komedi diye nitelediğini haber vererek İsmailin çok aptalca hareket ettiğini belirtir. (ibni Hallikan 1977: 11/524)

\section{B. Duvin'den Tikrit'e Gelişleri ve Tarih Sahnesine Çıkışları}

Necmeddin Eyyûb'un babası Şadî ile Selçuklular'ın Irak şahnesi Mücahidüddin Bihrûz arkadaş ve dost idiler. Bihrûz'un davetiyle Şadî, oğulları Necmeddin, Şîrkûh ve kendisiyle çalşsan askerlerle birlikte lrak'a gelerek bir süre Mücahidüddin'in hizmetinde bulundular (1126). (ibni'l-Esîr 1963: 119) Yeni gelen 
$390^{\text {* TAED }} 48$

Osman GüRBüZ

dostlarının hizmetinden çok memnun kalan Mücahidüddin, Şadîyyi kendi iktaı olan Tikrit muhafızlığına atamıştı. ibni Şeddâd, kale muhafızlı̆̆ı veya dizdarlık görevi yerine valilik ifadesini kullanır. (ibni Şeddâd 1994: 31) Burada kısa bir süre görev yapan Şadî ölünce, aklı, zekâsı ve olgun davranışlarıyla Bihrûz'un dikkatini çeken Necmeddin Eyyûb, babasından boşalan göreve getirildi. Başta ibni'l-Esîr, ibni Vasıl olmak üzere birçok tarihçi, Şadînnin Tikrit'teki görevinden bahsetmez, Necmeddin Eyyûb'un çalışmalarından söz eder. Buradan hareketle Şadînnin Tikrit valilĭginde değil bir başka görevde istihdam edildiği, Tikrit'e göderilenlerin oğulları olduğu hatıra gelir. Ancak Şadînin türbesinin Tikrit'te olduğu göz önüne alınırsa burada görev yapma ihtimali artar. Tikrit'in stratejik konumu yanında Bihrûz'un hazinelerinin, eş ve çocuklarının muhafaza edildiği yer olması hasebiyle önemi büyüktü. (Ebû Şâme 2002: 11/165) Diğer yandan Tikrit ve çevresindeki yerleşim alanlarında Kürt nüfusun meskûn olması sebebiyle Necmeddin Eyyûb ve kardeşi Şîrkûh'un burada görevlendirilmesinin altında yatan faktörleri daha iyi anlayabiliriz.

Necmeddin Eyyûb, Tikrit'teki valiliği esnasında oldukça başarıı bir yönetim sergiledi. Adalet, halkın memnuniyeti, dinî değerlere bağlılık, insanlarla iyi ilişkiler, üstün ahlakî meziyetler ve cömertlik yönetiminin asli unsurlarını oluşturuyordu (Ebû Şâme 2002: 11/164-165) Dindarlığı, iyilik severliği ve mükemmel yönetimiyle halkın gönlünde taht kurmuştu. İmâdüddin Kâtib elİsfahanî, amcası Azîz'in rakipleri tarafından Tikrit kalesine hapsedildiğini, rakiplerinin girişimiyle Bihrûz'un Necmeddin Eyyûb'tan amcasını öldürmesini istediğini, fakat Necmeddin'in her şeyi göze alarak bu emri uygulamadığını, Bihrûz'un bizzat kaleye gelerek kendi eliyle amcası Azîz'i katlettiğini nakleder ve onun bu olay karşısında takındı̆̆ yiğit ve insani tutumdan sitayişle bahseder. Burada onun çok kritik bir emre karşı çıkıp sonuçlarına katlanmayı göze alabilecek ilkeli tutumuyla karşılaşıyoruz. Onun benzer bir davranışına aşağıda anlatacağımız diğer bir olayla tanık oluyoruz.

525/1131 yılında İmâdüddin Zengî kuvvetleri, Halife Müsterşid ve Karaca es- Sakî askerlerinin âni baskınıla Tikrit yakınlarında yenilerek darmadağın oldu. Askerlerinden birçoğu ödürülürken karargâhındaki her şey yağmalandı. İmâdüddin perişan bir durumda Tikrit surlarının dibine vardı. Yaralı ve bitkin halde bulunan Zengî bir ip vasıtasıyla kaleye çekilerek yaraları tedavi edildi. Necmeddin Eyyûb, Zengînnin askerlerinin Dicle nehrini geçmesi için gemiler temin etmesinin yanı sıra beklenmedik misafirlerine olabildiğince yardımcı olup ikramlarda bulundu. (ibni Şeddâd 1994: 31; ỉbni Vâsıl 1957: 1/8) On beş gün kalede misafir edilen Zengî, Musul'a döndü. Son derece muhtaç bir durumda kendi şehrine dönen Zengî, Tikrit'e ulaşabilen inek sürüsü de dahil olmak 
kaydıyla savaş artı̆̆ı mal varlı̆̆ının peşi sıra gönderildiğini görünce, bundan çok etkilendi. Bu olay vasıtasıyla Necmeddin Eyyûb ve kardeşi Şîrkûh ilk defa tanışıyorlardı ve iki taraf arasında oluşan dostluk artarak devam etti. Necmeddin'in iyiliklerini unutmayan Zengî, onların Tikrit'te kaldığı yıllarda çeşitli armağanlar göndermeyi ihmal etmedi. (Ebû Şâme 2002: 11/166) Necmeddin Eyyûb'un Zengîye verdiği desteğin Bağdat'taki Mücahidüddin Bihrûz'a açtığı sıkıntıyı göz önüne getirirsek, Necmeddin Eyyûb ve Mücahidüddin Bihrûz arasındaki ilişkilerin giderek zayıfladığını düşünebiliriz. Nitekim Bihrûz Necmeddine bir elçi göndererek düşmanları olan Irak Selçukluları'na yapmış olduğu iyilik ve yardımın hesabını sormakta gecikmedi. Eline düşmüş öyle bir düşmanını cezalandırmadan salıverdiği için onu azarladı. (es-Sallabî 2007: 94)

Onların Tikrit'ten ayrılmalarında bardağı taşıran son damla diyebileceğimiz olay şöyle gelişti. Necmeddin'in kardeşi Şîrkûh kendisinden çekinilen heybetli birisiydi. Necmeddin sürekli kalede bulunur, fakat Şîrkûh zaman zaman kaleden iner, işlerini gördükten sonra dönerdi. Yine böyle bir dönüş esnasında kale sahibinin hristiyan kâtibinin dokunaklı sözleriyle karşılaştı; zaten araları açıktı. Esedüddin Şîrkûh hemen kılıcını çekerek kâtibi öldürdü, ayaklarından sürükleyerek kaleden aşağı fırlattı. Kendisinden çekindiklerinden dolayı kimse, onun yaptığı işten dolayı bir şey söylemeye cesaret edemedi. Olup bitenler çok geçmeden Bihrûz'un kulağına ulaştı. Bihrûz'un yanına varan bazı kimseler, onu Şîrkûh'un cür'etiyle korkutarak kabilesinin büyüklük ve kudretini, kardeşi Necmeddin'in halkın gönlünde taht kurduğunu söyleyip şimdiden işin çaresine bakmadığı takdirde çok geç olacağını bildirerek onu korkutmada başarıı oldular ${ }^{2}$.

Bütün bunlar ileride Bihrûz'un başına üstesinden gelemeyeceği sorunlar çıkarabilirdi. Bihrûz, kardeşinin yaptıklarından dolayı Necmeddin'i kınayarak, kaleyi mektubu kendisine ulaştıran naibine teslim etmesini istedi. Necmeddin baş üstüne diyerek, kalede bulunan bütün malları, aile bireyleri ve kendisine bağlı askerleriyle aşağı indi. Yukarıdaki satırlardan anlaşıldığı üzere Bihrûz ve Necmeddin arasındaki ilişkiler, tamiri mümkün olmayacak düzeyde gerginleşmişti. Necmeddin'in kardeşinin veya bazı iddialara göre kendisinin yapmış olduğu bir hatadan dolayı (ỉbni Vâsıl 1957: 1/8) bir açıklamaya ve özre yeltenmemesi, işin sonuna gelinip kararın önceden verildiği düşüncesini güçlendirmektedir.

${ }^{2}$ Bu konuda Necmeddin'in ok attığı bir sırada yanlışlıkla Bihruz'un adamlarından birisini öldürdüğ̈̈ ve utancından kaleyi terk ettiğini ileri sürenlerin olduğunu kaydetmemiz gerekir ( bkz. Müferric, 1/ 8). 
532/1137 yilında Esedüddin Şîrkûh ve Necmeddin Eyyûb, Tikrit'te Bihrûz'un hizmetinden ayrılarak Musul'a hareket ettiler. O gün Tikrit tarihî bir gün yaşamıştı. Çünkü Eyyûbî kardeşler, burada oldukça güzel bir yönetim sergileyerek yol kesenleri, huzuru bozanları, bozguncuları şehirden uzaklaştırmışlar, şehir mamurlaşırken her yanda emniyet sağlanıp ahalinin durumu düzelmişti. Yediden yetmişe herkes kaleden çıkarak onları uğurlamaya gelmişti. Kafile ayrılırken ağlama sesleri gözyaşlarına karışıyordu. (Ebû Şâme 2002: 11/167) iki kardeşin Tikrit'ten ayrıldığı gece Necmeddin Eyyûb'un bir erkek çocuğu dünyaya geldi. Çocuğun ismini Yusuf koyup Selâhaddin lakabını verdiler.

\section{Musul Günleri}

1137 yılında Necmeddin Eyyûb ve kardeşi Şîrkûh'un Musul'a gelişine Atabey Zengî çok sevindi, onları karşılamak için kafileler çıkardı, törenler düzenledi. Kadirbilir Zengî, çok sıkıntılı döneminde iki kardeşin yapmış olduğu iyilik ve konukseverliği hiç unutmayıp devamlı hatırında tuttu. Misafirlerini en güzel şekilde karşılayıp ikramlarda bulundu. Çok değerli iktalar vererek gönüllerini hoş tuttu. Zengînin askerleri arasına katılan kardeşlerin ikbali, i'tibarı günden güne arttı. Zaten Necmeddin ve kardeşi Şîrkûh, Atabey Zengî yanında saygın ve değerli bir konuma sahipti. (ibni'l-Esîr 1963: 119; ibni Şeddâd 1994: 31; ibni Vâsıl 1957: 1/8 ) Necmeddin Eyyûb siyasi kabiliyet ve pratik zekâsıyla ön plana çıkarken, Şîrkûh kısa zamanda Zengînnin en önde gelen komutanları arasına girmeyi başarmıştı.

iki kardeşin Atabey Zengînin memleketi Musul'da kısa zamanda ikbal merdivenlerini tırmanmalarının diğer bir sebebi ise, Musul veziri Cemâleddin ve Esedüddin Şîrkûh arasındaki dostluk idi. Zengînnin veziri olan Cemaleddin son derece saygın bir konuma sahip olup, bütün ülkenin müşrifi (denetçi) idi; Nusaybin, Rahbe gibi önemli merkezler onun iktası idi. Cemaleddin iki kardeşi Zengîye daha fazla tanıtmak, yakınlaştırmak için büyük gayret gösterdi. Vezir ve Şîrkûh arasındaki dostluk öyle ilerlemişti ki, aralarındaki sözleşmeye göre hangisi önce ölürse, diğeri onun nâşını Peygamber şehri Medine'ye nakledecekti. Nitekim Cemâleddin'in ölüm haberi Şîrkûh'a haber verilince dostunun cenazesini Medine'ye naklettirmişti. (Ebû Şâme 2002: 1/370)

534/1140 yılında Atabey Zengî, Şam bölgesinin önemli şehirlerinden Ba'lebek'i fethedince, Necmeddin'i buraya vali atadı. Çocukları Selâhaddin Yusuf henüz iki yaşındaydı. Yusuf un baba gözetimi altındaki çocukluk dönemi bu şehirde geçti. Hem babasının görevi hem de bulundukları kalenin Haçlılara komşu stratejik bir noktada oluşunun, onun müstakbel hayatını şekillendirmedeki etkisi açıktır, Yusuf baba eğitimi altında on iki yaşına kadar 
Ba'lebek'te serpilip büyüdü; daha o zamanlar olgunluk ve hâkimiyet emareleri görülmeye başlamıştı. (ibni Şeddâd 1994: 32) On dört yaşlarında ise şehirleri etrafındaki ovalara saldırıp ekili alanları yakıp yıkıp yağmalayan Frenklerle yapılan savaşlarda bulunmuş, kendi topraklarını ve bölge sınırlarını savunma faaliyetlerine katılmıştı.

541/1146 yılında Atabey Zengînin Caber kalesi önünde şehit edilmesinden sonra Dımaşk Atabeyi Muînüddin Üner, Ba'lebek kalesini kuşattı. Necmeddin Eyyûb, babaları İmâdüddin'den sonra Musul yönetimine geçen Seyfeddin Gazi'den yardım istedi. Çünkü valiliğini yapmış olduğu şehir Musul yönetimine bağlıydı; kalenin, Dımaşk Atabeyleri olan Börilerin eline geçmesini istemiyordu. Fakat Zengînin oğlu Seyfeddin Gazi, yönetime yeni geçmesinin yanında çevresindeki sorunlarla uğraşmaktaydı. Bu yüzden Necmeddin'in istemiş olduğu yardımı gönderemedi. Diğer yandan Ba'lebek kuşatması, kaleye giden suların kesilmesiyle dayanılmaz bir hal almıştı. Necmeddin kalenin zorla alınacağını gördügü için az zararlı olan anlaşmayla teslim yolunu seçti. Dımaşk'ta kendisine önerilen iktaları kabul ederek kaleyi teslim etti. Fakat Necmeddin'in kaleyi teslim ederek Dımaşk'ta ikamet etmesi, Nûreddin Mahmûd'un kuşkulanmasına yol açtı. Bu yüzden Mecdeddin Daye'yi çağırarak bütün işlerinin ve ülkesinin niyabetini kendisine bıraktı. Bu durum Esedüddin Şîrkûh'un çok ağırına gitti. Belki de Necmeddin Eyyûb, Zengîleri bırakarak Dımaşk'a yerleşmesinin ardından kardeşinin azar ve kınamasına maruz kalmış olabilir. Yine bu sebeple 547/1152 yılında oğlu Selâhaddin Yusuf u Halebte amcası Şîrkûh'un yanına gönderip, onun askerleri arasına katılmasını istemiş olabilir. (Ş. Mustafa 1998: 40) Öyle görünüyor ki Necmeddin iktasının başında kalırken oğlu Yusuftan amcasına durumu açıklamasını istedi. Buna göre Dımaşk'ta kalmasının daha iyi olacağını, ancak bu durumda Zengîler adına gelişmeleri takip etmesinin mümkün olacağını, yoksa ikta dışında pek bir kazancının olmadığını, Dımaşk emirleri arasında ilerlemesinin mümkün olmadığını, Zengîler'in idarî bakış açısına sahip olduğu için bu insanlar arasında hep garip kalacağını bildirmesini istedi. Bu haberleri götürmesinin yanı sıra yıldızı parlamakta olan Nûreddin'in devleti içinde amcasının gözetiminde genç Selâhaddin'in yer almasını istemiş olabilir. (Ş. Mustafa 1998: 40)

Böylece kardeşi Şîrkûh, Zengînin küçük oğlu ve Seyfeddin Gazi'nin kardeşi Haleb Emîri Nûreddin Mahmûd'un yanında kalırken, Necmeddin Eyyûb, Böriler'in yanında kalarak Dımaşk emirleri arasına katılmış oldu. (ibni'l-Esîr 1963: 120; íbni Vâsıl 1957: 1/9-10) Şîrkûh cesareti, yiğitliği, atılganlığıyla kısa sürede Nûreddin Mahmûd'un en yakın adamları arasına girmeyi başardı. Farklı 
taraflarda kalmalarına rağmen iki kardeş arasındaki ilişkiler eskisi gibi devam etti.

Kardeşler arasındaki irtibat ve işbirliği, Dımaşk'ın Nûreddin Mahmûd tarafindan ele geçirilişinde bir kez daha ortaya çıkar. Nûreddin Mahmûd, Şam bölgesinde İslam birliğini gerçekleştirmek, Haçlılarla mücadelesini sürdürebilmek ve Frenklerle işbirliğinden çekinmeyen Dımaşk Atabeyliğini ortadan kaldırabilmek için kararını çoktan vermişti. Daha önce babası İmâdüddin Zengî, Dımaşk'ı almak için girişimlerde bulunmuş ancak her defasında başarısız olmuştu. Nûreddin'in emriyle Esedüddin Şîrkûh Dımaşk'ta bulunan ağabeyi Necmeddin Eyyûb ile haberleşip şehrin fethi konusunda kendilerine yardımcı olmasını istedi; Necmeddin onların taleplerine olumlu cevap verdi. (ibni'l-Esîr 1963: 120) 1151 yılında Nûreddin Mahmûd Dımaşk'ı kuşattı. Kuşatma devam ederken iki taraf arasında görüşmeler devam etmekteydi. İşte bu görüşmelerde Nûreddin Mahmûd'un delegesi Şîrkûh, Dımaşklılar adına görüşmeleri sürdüren temsilci ise Necmeddin Eyyûb idi. Yapılan görüşmeler sonunda Dımaşk'ın Nûreddin Mahmûd'a bağlanması kararlaştırıldı. ỉbni'l-Esîr'in bildirdiğine göre, iki kardeş bu destek karşıllı̆ında Dımaşk ve başka şehirlerde birçok ikta ve emlak şartı koşmuşlar, Nûreddin de onların isteklerini kabul etmişti. (ibni'l-Esîr 1963: 120)

Fakat daha sonra Dımaşklılar bu anlaşmaya uymadılar. Askalan'ın Haçlılar tarafından kuşatılması esnasında şehir halkına yardımcı olmadılar. Şehrin Haçılıar tarafından zaptından sonra sıranın Dımaşk'a geldiğini sezen Nûreddin, Şîrkûh'u bin kişilik bir kuvvetle Dımaşk üzerine gönderdi; bunun üzerine Atabey Muciruddin Abak Frenkleri yardıma çağırdı. Öte yandan Necmeddin Eyyûb aracılığıyla Nûreddin Mahmûd taraftarları Şîrkûh ile irtibata geçip Nûreddini yardıma çağırdılar. Askerleriyle Dımaşk önlerine gelen Nûreddin kuzeyden, Şîrkûh ise güneyden şehre girdi. Dımaşk'ın alınışından sonra etrafta bulunan şehir ve kalelerin fethi tamamlandı. Böylece siyasi birlik önemli ölçüde sağlanmış oldu. Daha önce değinildiği gibi bu sonucun elde edilmesinde Eyyûbî kardeşlerin azımsanmayacak katkıları oldu. Doğal olarak Dımaşk'ın fethinden sonra iki kardeşin devlet içindeki güç ve saygınlıkları arttı. Şîrkûh, Nûreddin Mahmûd'un Dımaşk naibi olurken, Necmeddin Eyyûb gıptayla bakılan özel ayrıcalıklara sahip olmuştu. (ibni'l-Esîr 1963: 120) Genç Selâhaddin'in Nûreddin Mahmûd ile tanışması bu dönemlere rastlar. Babası onu el- Melikü'l-Adil Nûreddin Mahmûd ile tanıştırıp onun himaye ve gözetimine tevdi etti. Kısa zamanda Nûreddin Zengînnin gözüne girmeği başaran Yusuf, ikbal merdivenlerini birbiri ardı sıra tırmanarak Mahmud'un yakın adamları arasına yükseldi. (ibni Şeddâd 1994: 32) Aralarındaki yaş farkına rağmen Nûreddin Mahmûd'a eşlik ediyor, onunla 
Dımaşk kalesinin yanındaki çayırda çevgân oynuyor, Haleb'te ikamet eden amcası Şîrkûh ile Nûreddin arasında gidip gelerek irtibatı sağlıyordu. (Ş. Mustafa 1998: 64)

\section{Birinci Mısır Seferi}

Fatımî döneminin sonu yaklaşırken Mısır, kavga ve karışılıklar içinde yüzmekte olup, ülkede anarşi hâkimdi. Vezirler tarafından yönetilen Mısır'da sık sık iktidarlar alaşağı ediliyor, yönetimi ele geçiren emirler, daha güçlüleri ortaya çıkınca yerlerini onlara bırakmak zorunda kalıyorlardı. Mısır'in bu durumu Haçlıların iştahlarını kabartıyor, Dımaşk'ta Nûreddin'e kaptırdıklarını burada kazanarak onu iki yandan kuşatmanın hesaplarını yapıyorlardı. Diğer yandan Nûreddin'in burayı ele geçirmesinin kendilerinin sonunu getireceğini iyi biliyorlar ve bundan çok korkuyorlardı. (ibni'l-Esîr 1963: 121) Nûreddin açısından Mısır daha büyük bir önem arz ediyordu. Askalan'ı ele geçiren Haçlıların bölgede ikinci bir üs kurmalarına izin vermeyecek, islâm dünyasında kök salmalarının önüne geçecek, hac ve ticaret yollarının güvenliğini sağlayacak, kendi ülkesini batıdan kuşatan Haçlıların güneyden da kuşatmalarına firsat tanımayacaktı. Mısırlıların o zamanlar vezirliğini Şâver isimli birisi yürütmekteydi; ancak Hacib Dırğam ortaya çıkarak, Şâver'i uzaklaştırıp yerine geçmenin planlarını yaptı. (ibni Şeddâd 1994: 75) Dırğam, taraftarlarından oluşan büyük bir askeri kuvvetle ilerleyip Şâver'i Mısır'dan çıkardı, oğlunu öldürüp vezareti ele geçirdi. (ibni Vâsıl 1957: 1/37) Mısırda halkın olup bitenlere bir şey diyebilecek halleri yoktu, kural böyleydi; kim güçlüyse yönetimi üstlenir, ahali de yeni yönetimle yoluna devam ederdi. (ibni Şeddâd 1994: 75)

Şâver yenilip Mısır'dan çıkarılınca zaman geçirmeden 558/1163 Şama varıp Nûreddin Zengînin hizmetine girdi. Başına gelenleri kendisine anlatarak düşmanına karşı onun yardımını istedi. Nûreddin bazı endişe ve tereddütler taşımasına rağmen ( ibni'l-Esîr 1963: 121; ibni Vâsıl 1957: 1/138) hem Şâver'e yardım hem de Mısırın durumunu araştırıp kendisine bildirmesi için Esedüddin Şîrkûh'a hemen yola çıkmasını bildirdi. Şîrkûh hazırlıklarını tamamlayıp 558/1164 yılında ve büyük çoğunluğu Oğuzlar'dan meydana gelmiş bir birlikle (Şeşen 1987: 42) birlikte yola koyuldu. Aslında 27 yaşında bulunan Selâhaddin'in bu sefere çıkmayı istememesine rağmen amcasını kıramadığı görülmektedir. Şîrkûh'un ona ihtiyacı vardı. Onu beraberine alarak hem görüşlerinden istifade etmek istediğini hem de askerlerinin başına getirmek istediğini söyleyerek Mısır'a vardılar. Sina yarımadasının güneyini takip eden yolu izleyen birlik Kahire yakınlarında Bilbis'te bekleyen Mısır ordusunu yendiler. 
Onların Mısır'a gelişi ahali nezdinde büyük yankı uyandırdı; korkuya kapıldılar. Düşmanına karşı Şâver'e yardım eden Şîrkûh, Dırğam'ı uzaklaştırarak Şâver'i yeniden Mısır Fatımî vezaretine oturttu. Bu arada ülkenin siyasi durumu kendisini ümitlendirmişti; çünkü orada işler gelişigüzel yürümekte olup memleketin sahibi yok gibiydi. Fakat Şâver iktidara geçtikten sonra Nûreddin'le varılan anlaşmanın şartlarını yerine getirmeyerek Şîrkuh'un derhal Mısır'ı terk etmesini istedi. Bunun üzerine Şîrkûh askerlerinden bir kısmını Selâhaddin komutasında Bilbis'te bekletirken Şâver'i Kahire'de tekrar kuşattı. Ne var ki Şâver'in çağrısıyla Haçlıların Bilbis'i kuşatmalarını haber alınca, Kahire'yi bırakarak Selâhaddinin yardımına koştu. Üç ay devam eden Haçlı kuşatması Nûreddin'in Harim'i fethedip Banyas'a ilerleme haberleriyle kaldırıldı. Haçlılarla yapılan anlaşma gereğince Mısır'a vardıkları yılın Zilhicce/Kasım ayında amca yeğen birlikte Şam'a döndüler. Şîrkûh, Selâhaddinin düşüncesini öğrenmeden hiçbir işe girişmiyor, onsuz bir adım bile atmıyordu; çünkü ona danışarak başladığı işlerde hep başarılı olmuş, onun isabetli karar ve düşüncelerine yakından tanık olmuştu. Şîrkûh bir yandan Şam'daki işlerini yürütürken diğer yandan Mısır'a dönmenin hesaplarını yapıyor, bu konuyu Sultan Nûreddin Mahmûd'a açıyor ve konuyu nasıl çözüme kavuşturacaklarını kararlaştırmaya çalışıyorlardı.

\section{E. ikinci Mısır Seferi}

Esedüddin Şîrkûh yeniden Misır'a dönmek ve orada emellerini gerçekleştirmek hususundaki düşüncelerini sağda solda söylemekten geri durmuyor, her yerde anlatıyordu. Bu haberler Şâver'in kulağına ulaşınca Şîrkûh'un niyetini anladı; Türklerden ülkesine gelecek tehlikeden dolayı dehşete kapıldı. (ibni Şeddâd 1994: 76) i̇çini kaplayan bu korkudan kurtulmak için Franklar ile mektuplaşarak onları ülkesine davet etti. Böylece onlar Mısıra gelecekler, Şâver'e yardımcı olup düşmanlarının kökünü kazıyacaklardı. Bu haber Şama ulaşınca Nûreddin ve Şîrkûh'u telaşlandırdı; Mısır'ın Frankların eline düşmesinden endişelendiler. Şîrkûh hazırlıklarını tamamlayınca Nûreddin tarafından kendisine gönderilen askerlerle birlikte Mısı'ra hareket etti; Selâhaddin gönülsüzlüğüne rağmen Sultanın arzusuyla bu seferde de amcasıyla birlikte yola çıkmak zorunda kaldı.

562 senesinde başlayan yolculuk neredeyse Mısır'a ayak basan Franklarla aynı günlerde son buldu. Cîze'de karargâhını kuran Şîrkûh, casusları vasıtasıyla üzerine gelen Haçlı-Mısır birleşik kuvvetlerinin çokluğunu öğrenince, önce Şâver'e bir elçi göndererek, amacının barış olup Frenklere karşı beraberce savaşmak istediğini belirtti. Ama Şâver elçiyi öldürüp, Nil köprüsünden 
asılmasını emretti. ${ }^{3}$ Bunun üzerine Şîrkûh komutanlarını toplayıp durumu görüştü. Çoğunluk, 2000 kişilik küçük bir kuvvetin on binlerce askere karşı koyamayacağını, uygun olanın Nil'in doğusuna geçip Şam'a dönmek olduğunu söyleyerek "-Burada yenilirsek, herkesin düşman olduğu bu ülkede kime sığınıp nereye başımızı sokacağız, ellerine geçirseler kanımızı içecekler" dediler. Bunun üzerine Nûreddin'in memlûklerinden Şerefeddin Bozkuş: “-Ölmek ve yaralanmaktan korkanlar, hükümdarların hizmetinde çalışmasınlar. Ya çiftçilik yapsınlar veya evde kadınlarla otursunlar. Eğer biz zafer kazanmadan veya mazaretsiz geriye dönecek olursak, Nûreddin elimizdeki toprakları ve tahsisatlarımızı alır. Şimdiye kadar yaptığımız bütün harcamaları geri ister. Bize, Müslümanların mallarını yer, düşmanlarından kaçar, Mısır gibi bir ülkeyi kafirlere teslim edersiniz, der " deyince, Şîrkûh, "işste uyacağım görüş” dedi. (ibni'l-Esîr 1963: 121; ibni Vâsıl 1957: 1/150) Yeğen Selâhaddin de amcasının görüşüne katıldı, onaylayanların sayısı arttı ve durup savaşmaya karar verildi. (ibni Vâsıl 1957: 1/150) Şâver, Franklar ve Mısırlılar hep birlikte Şîrkûh'a karşı saldırıya geçtiler; Düşmanların merkeze hücum edeceğini kestiren Şîrkûh, Selâhaddin kuvvetlerini merkeze yerleştirerek, saldırı başlayınca düzenli olarak çekilmelerini tembihleyip seçme askerleriyle sağ kanada yerleşti. Tam da düşündüğü gibi düşman askerleri geri çekilen Selâhaddin'i takibe koyulup yağmaya başlayınca, Şîrkûh kuvvetleri hücuma geçerek düşmanı darmadağın etti, Frenk kralı esir düşmekten zor kurtuldu. Son derece zor şartlar altında kazanılan bu zafer için ibni'l-Esîr: "iki bin süvarinin Haçlı ve Mısır kuvvetlerini yenmesi, tarihin kaydetmiş olduğu inanılması güç başarılardan birisidir" der. (ibni'l-Esîr 1963: 133) Bu esnada Nûreddin'in isabetli bir kararla Trablus yakınlarında Frank topraklarına karşı saldırıya geçip Muneytıra kalesini ele geçirmesi, Mısırda Şîrkûh'a karşı savaşan Haçıların hesaplarını altüst etti ve onları geri dönmeye mecbur etti. Diğer yandan Esedüddin de Franklar ve Mısır birleşik kuvvetlerine karşı giriştiği çarpışmalarda bitkin düşmüş ve bu sebeple o da Mısırdan ayrılmıştı. Zaten Mısır'dan ayrılır ayrılmaz Haçlılarla anlaşma yapılmış ve tarafların birlikte ülkeden çekilmeleri kararlaştırılmıştı. Tekrar Şam’a döndüler; ancak bu sefer kalplerini ürperten korku daha çok artmışı. Çünkü orada daha önce fark ettikleri yönetim zaafiyet ve boşluğunu Franklar da sezmişlerdi. Bu durum oldukça tehlikeli sonuçlar doğurabilirdi. (ibni Şeddâd 1994: 77)

\footnotetext{
${ }^{3}$ Hatta Şirkuh'un, beraberce Frenklere karşı savaşalım teklifine, “ Bunlar Frenk değil ferec (rahatlık-huzur) "diyerek mukabelede bulunmuştu ( Bkz.Ş. Mustafa, Selâhaddin, s.68).
} 
$398^{* \text { TAED }} 48$

Osman GÜRBÜZ

\section{F. Üçüncü Mısır Seferi}

Franklar Mısır topraklarına göz dikince daha önce yapmış oldukları barış antlaşmasını yok sayıp saldırıya geçmeğe karar verdiler. Aslında kral Amaury, Mısır'daki taraftarlarının ısrarlı çağrıları, Avrupa'dan yeni gelen Haçlıların baskısına rağmen Mısır seferine çıkmak istemiyor, Mısırla var olan ilişkilerinin bozulmasının Nûreddin'in işine yaramasından korkuyordu. (Ebû Şâme 2002: 11/32) Şâver'e karşı isyan hareketi başlatan grubun Haçlılara sığınması, Şâver'in gözlerini açtı. (Şeşen 1987: 48) Oysa Şâver'in Haçlılarla yapmış olduğu anlaşma gereğince Kahire'de bir Haçlı birliği bulunuyordu. Şâver, bu birliği geri gönderip, Haçlılara vaat ettiği vergiyi tek taraflı iptal ederek, yardım için peş peşe Nûreddin'e elçiler göndermeye başladı. Bu davranış Nûreddin ve Şîrkûh'un sabrını taşıran son damla olmuştu. (ibnii Şeddâd 1994: 78) Ancak Sultan Nûreddin bu kez de ordusunun başında Mısır seferine çıkamıyordu. Bunun iki sebebi vardı. Birincisi ülkeden ayrılma durumunda Haçlılardan gelebilecek tehlikelere karşı ülkesinin savunmasız kalması, diğeri ise Musul Atabeyi Zeynüddin Ali'nin ölümüyle ülkesini ve kalelerini Atabey Kutbeddin'e teslim etmesiydi. Oysa daha önce babası Atabey Zengîye ait olan bu kalelerin Nûreddin'in eline geçmesi gerekiyordu; işte şimdi bu firsat doğmuştu. Nûreddin'in malî ve askerî yardımıyla desteklediği Esedüddin başta kendi şahsı olmak üzere malını, ailesini, adamlarını bu yola koyarak sefere çıktı. Bu sefer için iki bin seçme asker ve altı bin Türkmen toplanmıştı. Bununla yetinmeyen Nûreddin, İzzuddin Curdik, Ğarsüddin Kılıç, Şerefüddin Bozkuş, Nasuhuddin Humartekin, Aynuddevle b. Yarûkî, Kutbeddin Yınal gibi seçkin emir ve memlûklarını da gönderdi. (Ebû Şâme 2002: 11/34; ibni Vâsıl 1957: 1/150) Frankların planlarından haberdar olan Şâver, diğer yandan Şîrkûh'a adamlar salarak zor durumda olduğunu belirtip acele yardım çağrısında bulundu. Şîrkûh komutasındaki kuvvetler 8 Ocak 1169 yılında Mısıra ulaştı.

Onun Mısır'a Şâver'in davetiyle geldiğini öğrenen Franklar, ümitsizliğe düşüp geldikleri gibi geri döndüler. Şîrkûh ise Mısır'da kaldı; zaman zaman Şâver kendisinin ziyaretine geliyor, ona harcamış olduğu masraflar karşılığında para ve mal göndereceğini vaad ediyor; ancak göndermiyordu. Mısırlılar artık şunu iyice bellemişlerdi ki Haçlılar ne zaman firsatını bulsalar ülkeyi ele geçirecekler ve bu durumda Şam'dan yardım istemelerinin fazla bir anlamı olmayacaktı. İși kökten halledebilmenin yolu, Şâver'den kurtulup yerine Şîrkûh'u vezir olarak tayinden geçiyordu. Şâver kendi yönetimini sürdürebilmek için bazen Franklardan bazen de Şamdan yardım istemekte bir mahzur görmüyordu. 18 Ocakı169 günü Şâver'i tutuklayıp durumu halifeye bildirdiler. Halife Âzıd'ın isteği ile, bir çadıra hapsedilen Şâver'in kellesi kesilerek halkın önüne firlatıldı. 
664 senesi Rebiülahir ayında kendisine gönderilen vezirlik hil'atlarını giyinen Esedüddin Şîrkûh, doğruca saraya giderek yeni görevine başladı. (ibni Şeddâd 1994: 80)

\section{G. Şirkûh'un Ölümü ve Yerine Selâhaddin'in Geçmesi}

Ancak onun vezirliği yalnız iki ay beş gün sürmüştü.(Ebû Şâme 2002: 11/47) Esedüddin Şîrkûh boğazına düşkündü, oburdu. Kırmızı eti oldukça fazla miktarda yer, bu yüzden sıkça hazımsızlık ve reflü sorunlarıyla boğuşurdu. (ibni Şeddâd 1994: 80; ibni Vâsıl 1957: 1/162) Bazen bu sebeple oldukça sıkıntılı durumlara düşerdi. Yine böyle bir hastalık ve şiddetli hazımsızlık nöbetiyle 564/1169 yılında vefat etti. Vezaret makamı için birçok emir ve komutan yarışmasına rağmen Halife Âzıd tercihini Selâhaddin'den yana kullandı. Onu tercih etmesininnedeni, diğer emirlere göre askerlerinin azlı̆̆ sebebiyle, kendisine karşı koyamayacağı ve bu yüzden iktidar gücünün kendi elinde kalacağı düşüncesinde olmasıydı. (ibni'l-Esîr 1963: 142) Diğer emirlerin Selâhaddin'in vezirliğini kabullenememeleri Fakih Ziyaeddin ìsa'nın çabalarıyla aşıld. ${ }^{4}$ Onun yönetime gelmesiyle devlet işleri en güzel şekilde çekip çevrilmeğe başlandı. Askerlere cömertçe dağıttığı mal mülk sebebiyle ona duyulan muhabbet ve bağlılık artarken ülkedeki huzur ve güven umulmadık ölçüde arttı. Bundan dolayı Allaha şükreden Selâhaddin, içkiye tövbe ederek (ibni Şeddâd 1994: 81) eğlenceye sırtını çevirdi. Devlet adamlığının gerektirdiği vakar ve ciddiyet içinde kendini ülkesinin ve halkının hizmetine verdi. Bir süre sonra kardeşlerinin gelmesini isteyen Selâhaddin'in isteğine karşı Turanşah Mısır'a gönderildi. Nûreddin Mahmud'un Mısır'a giderken Turanşah'a söyledikleri manidardır: "Eğer sen otururken etrafında sana hizmet etmekte olan bir Yusuf beklentisi içindeysen, sakın gitme, ülkede karışıklık çıkarırsın; o zaman seni getirip cezalandırırım. Eğer ona Mısır hâkimi ve benim oradaki temsilcim gözüyle bakar, bana hizmet ettiğin gibi hizmet edersen, git, onu destekle ve yardımcısı ol". (ibni'l-Esîr 1963: 143; Ebû Şâme 2002: 11/32)

Mısır'ın Selâhaddin yönetiminde günden güne gelişip güçlenmesi Frankları rahatsız ediyor, bu durumun ileride başlarına getireceği sıkıntıları şimdiden görüyorlardı. Bunun için iktaları kesilen Sudanlı askerlerleri kışkırtıp Selâhaddin'in sarayına karşı yürüyüşe geçireceklerdi. İsyanın başını Hadımağası Necah çekiyordu. Selâhaddin komplodan haberdar oldu; ama bunu umursamadığını vehmettirerek dikkatle olanları gözetledi. Görevlendirdiği birisi

\footnotetext{
${ }^{4}$ Bu emîrler arasında Seyfeddîn Maşdub, Selâhaddîn'in dayısı Şihabüddîn el-Hârimî ve Kutbeddîn gibi Kürt asıllı emîrler de bulunmaktaydı. ( Bkz.lbnü'l-Esîr, el-Bâhir, 142;ibn Vasıl, Müferricü'lKürûb, 1/150)
} 
$400^{*}$ TAED 48 Osman GÜRBÜZ

vasıtasıyla, korumasız gezintiye çıktığı bir sırada Necah'ı öldürttü. Necah'ın öldürülmesinden sonra 50 bin Sudanlı liderlerinin intikamını almak için Selâhaddin'in sarayına doğru yürüyüşe geçti. Turanşah komutasındaki kuvvetler ayaklanmacılara karşı harekete geçti; ancak Âzıd'ın isyancıları desteklemesi, Turanşah kuvvetlerini zor durumda bıraktı. Turanşah'ın girişimleriyle Âzıd, isyancıları desteklemekten vazgeçince, Sudanlıların moralleri bozuldu ve yenilgiye uğrayıp Saîd taraflarına kaçtılar. Eğer Haçlılar planlarında başarılı olabilseydiler, isyancılar içeriden kendileri dışarıdan saldırarak Selâhaddin ve askerlerini Mısır'dan söküp atacaklardı.

Haçlılar, problemi daha fazla büyümeden çözüme kavuşturmak için Bizanslılarla birlikte Dimyat'a bir çıkarma harekâtında bulundular. Şehir deniz ve kara yollarının kavşak noktasında yer aldığı için her iki yönden gelebilecek yardımlar daha baştan engellenmiş olacaktı. Bunun üzerine Sultan Nûreddin Haçlıları oyalamak, dikkatlerini dağıtmak için Kerek kalesini kuşattı; ancak sahildeki Frankların kendisiyle savaşmak üzere hareket ettiklerini duyunca kuşatmayı kaldırarak onlara doğru yöneldi. Ne var ki bir karşılaşma ve savaş olmadı. Sultan Nûreddin Mahmûd Haçlıların Dimyat'a şiddetle saldırdıklarını haber alınca, hızla Dimyat'ta savaşan Müslümanların yardımına koştu. İçerden kaleyi savunan askerlerin, dışarıdan Nûreddinin askerlerinin saldırısıyla sıkışan Haçlılar, panik içinde kaçışmaya başladılar. Kuşatma aletleri ve ağırlıkları yağmalanan düşman kuvvetlerinin büyük kısmı katledildi. Dimyat saldırısının başarısızlığa uğramasıyla Selâhaddin, iç ve dış düşmanların hamlelerini ustalıkla savarak Mısır'da hâkimiyetini sağlamlaştırmış oldu. Ancak Mısır'da yeni durumdan rahatsız olan sadece Haçlılar değildi. Selâhaddin vasıtasıyla Nûreddin Mahmûd'un bu topraklar üzerindeki güçlü hâkimiyeti, Halife Âzıd'ı da rahatsız etmiş ve ileride kendi hâkimiyetini (Ebû Şâme 2002: 11/94) güçlendirecek girişimlere sevk etmişti. Âzıd, Nûreddin'e bir mektup yazarak ülkesinde bulunan Türklerin ayrılmasını, yönetimin yalnız Selâhaddin ve yakınlarına kalmasını istiyordu. Nûreddin, Frenklerin yenilgisini kutlayarak başladığı mektubunda Türkleri överek, şöyle diyordu: “ Ben Frenklerin keskin mızraklarına ancak Türklerin oklarıyla karşı konulabilir diye onlara güvenip gönderdim. Frenkler sadece onlardan korkarlar; eğer onlar olmasa Mısır'ı ele geçirmek için iştahları daha çok kabarırdı. Belki de Yüce Allah (c.c.) sayısız nimetlerine ilaveten Mescidi Aksa'nın fethini de nasip eder".

\section{H. Necmeddin Eyyâb'un Mısır'a Gelişi}

Mısır'da gücünü pekiştiren Selâhaddin, Sultan Nûreddin Mahmûd'a babası Necmeddin Eyyûb'un Misır'a gönderilme arzusunu iletti. Tüccarlar ve Selâhaddin'in dost ve ahbaplarından oluşan kalabalı̆̆ın eşlik ettiği askerler 
arasında Necmeddin Mısır'a hareket etti. (Ibni Vâsıl 1957: 1/85) Nûreddin Selâhaddine verilmek üzere Necmeddin ile çok değerli hediyeler gönderdi. Nûreddin, yola çıanların să̆ salim Mısır'a varmalarından endişe edip Haçlılardan gelebilecek bir saldırıyı uzaklaştırmak için Kerek üzerine bir sefer düzenledi. Frenkleri meşgul etmek için mancınıklar kurup kaleyi kuşattı. Daha sonra yola koyularak Aştara denilen yere vardı. Burada karargâhını kurarak düşmanı uzun süre gözetledi; daha sonra kafile Mısır'a ulaştı. Bu buluşma Yusuf Peygamber'in aynı topraklarda ailesiyle görüşüp kavuşmasını hatırlara getiriyor, benzer renkler, kokular, esintiler taşıyordu. (ibni Şeddâd 1994: 85; Ebû Şâme 2002: 11/99; íbni Vâsıl 1957: 1/185) Mısır veziri Selâhaddin Yusuf, bütün devlet erkânıyla şehir dışına çıkıp, bineklerinden inerek son derece saygı ve edep içerisinde babasını karşıladı. Fatımî halifesi Âzıd da kafileyi karşılamaya çıkanlar arasında bulunuyordu. Daha önce hiç kimse için böyle bir karşılama töreni yapılmamıştı. (Ebû Şâme 2002: 11/99) Vezaret sarayına geçildi. Selâhaddin kendi işgal ettiği vezaret görevini babasına teklif ederek, kendi yerine onun geçmesini istirham etti. Babası bu cömert davranışa " Oğlum, Cenab-ı Allah bu makama liyâkatından dolayı seni seçti; mutluluğun yer değiştirmesine gerek yok " diyerek nazikçe mukabelede bulundu. Bunun üzerine Necmeddin Eyyûb Mısır hazinelerinden sorumlu yönetici olarak görevlendirildi. (ibni Şeddâd 1994: 85; Ebû Şâme 2002: 11/99; ỉbni Vâsıl 1957: 1/186) Selâhaddin babası, kardeşleri ve diğer aile bireylerine iktalar bağışladı. Mısır olağanüstü günlerden birini yaşamaktaydı. Merhum Necmeddin Eyyûb, çok cömertti, kimseyi eli boş çevirmezdi. Son Fatımî Halifesi Âzıd ölünceye kadar bu görevini sürdürdü.

\section{Fatımî Hilâfetinin Kaldırılması}

ibnii Ebî Tayy, Abbâsî Halifesi Müstencid'in, Nûreddin'e yazdığı mektupta, Mısır'da Abbâsîler adına hutbe okutmayı geciktirdiği için eleştirdiğini, bunun için babası Necmeddin'i Nûreddin'in Mısır'a gönderdiğini ve onunla yolladığı mektupta Abbâsîler adına hutbe okumayı geciktirmemesini emrettiğini, belirtir. (Ebû Şâme 2002: 11/99) Fakat hutbenin değiştirilmesi için Necmeddin'in gönderilmesine bazı araştırmacılar karşı çıkar ve Ebu Şâme 'nin bu görüşünün diğer tarihçiler tarafından paylaşılmadı̆̆ına işaret ederler. (Ş. Mustafa 1998: 89) Daha Şîrkûh'un birinci seferinden sonra Abbâsî Halifesi tarafından gönderilen diğer bir mektupla aynı istek tekrarlanmıştı. Nûreddin, Mısır-Suriye güçlerinin Haçlılara karşı birleştirilmesi için Fatımî hilafetinin ortadan kaldırılmasını şart görüyordu. Bunun için Selâhaddin, 1169 yllından itibaren bir dizi Sünnî reformlara girişti. Ezher'deki Fatımî propaganda merkezini kapatarak sünnî öğretiyi yayan medreseler açtı. Şiî tarzı ezanı kaldırarak yerine sünnî ezanı okutmaya başladı. Fatımî kadıları azlederek yerine sünî kadılar tayin etti. Bunlara 
ilaveten Halife Âzıd'ın alaylı Cuma ve bayram namazlarını yasakladı. (Şeşen 1987: 58) Sikkelerin üzerinde yazılı "Aliyyü veliyullah" ifadesini kaldırtıp büyük camilerde namazların birleştirilmesi uygulamasını (cem) yasaklattı. (Ş. Mustafa 1998: 92) 1171 Haziranında Nûreddin, Selâhaddine yeni bir mektup yazarak hutbenin Abbâsîler adına okunmasını emretti. Zaten Mısır kamuoyunda mesele uzun zaman boyunca tartışılmış, bu değişime Mısırlılar fikren hazır hale gelmişti. Buna rağmen Selâhaddin ihtiyatı elden bırakmayarak Fatımî emirlerden her birinin etrafına geceden Şamlı birlikleri pusuya yatırarak gerekli tedbirleri aldı. Herhangi bir kıpırtı durumunda kıskıvrak yakalanacaklardı. (Ş. Mustafa 1998: 108) Halife Âzıd 1171 senesi Ağustos ayında ağır bir hastalığa yakalanmış, bundan da yararlanılarak 10 Eylül 1171 Cuma günü hutbe Abbâsiler adına okutulmuştu. (Şeşen 1987: 58) Bundan üç gün sonra Âzıd öldü, sarayına el konarak malları müsadere edildi; böylece Fatımî hilafetine son verilmiş oldu. Mısır'da yönetimin dizginleri bütünüyle Selâhaddin'in eline geçmişti. Bundan sonra hem Nûreddin hem de Selâhaddin farklı bölgelerde savaş hazırlıklarını sürdürdüler.

568/1173 yllına kadar Selâhaddin Mısırda adaletli, cömert bir yönetim sergileyerek halkın ve askerlerin memnuniyetini kazandı. Aynı yıl Selâhaddin ve Nûreddin Mısır Şam yoluna hâkim bir arazide bulunan Kerek ve Şevbek Prinkepsliği'ne müşterek bir sefer yapmayı kararlaştırdılar. Selâhaddin 1173 yılında Mısır'a daha yakın bulunan Şevbek kalesini kuşattı. Diğer yandan Nûreddin Dımaşk'tan yola çıkarak Kerek kalesini kuşattı. Fethe ilk önce bu kalelerden başlanmasının birinci sebebi, en yakın mesafede bulunmaları; ikinci sebebi ise, stratejik konumda bulunan bu iki kalenin Misır-Suriye yolunun üzerinde bulunuyor olmaları sebebiyle kervanların geçişlerine engel oluşturmalarıydı. Bizzat Sultanın bile bu yoldan geçmesi imkânsızdı. Onun için evvela bu kalelerin alınıp yolun açılması gerekiyordu. Aksi halde Suriye- Mısır arasındaki bağlantının kurulabilmesi mümkün değildi. (ibni Şeddâd 1994: 85) Amaury'nin Mısır'a hareket ettiğini haber alan Selâhaddin kuşatmayı yarıda keserek Kahire'ye vardı. 1173 yılında Selâhaddin, Nûreddine götüreceği hediyeleri yanına alarak Kerek-Şevbek Prinkepslï̆i'ne ikinci bir sefer düzenledi. Ancak bu defa da babasının ölümü ve Fatımîlerin bazı karışıklıklar çıkaracağı duyumunu aldığı için geri dönmek zorunda kaldı. (Şeşen 1987: 60)

\section{K. Nureddin ve Selâhaddin Arasında Soğukluk ve Necmeddin'in Tavrı}

ibni'l-Esîr, yukarıda özetlemeye çalıştığımız Kerek-Şevbek seferini biraz farklı anlatarak Selâhaddin ve Nûreddin, arasında bir kırgınlıktan bahsetmektedir. Ona göre olaylar şöyle gelişti: NûreddinSelâhaddin'e haber göndererek, asker toplayıp Kerek'e hareket etmesini, kendisinin de askerlerini alıp oraya geleceğini ve birlikte Haçlılara karşı savaşacaklarını bildirdi. Selâhaddin 
gecikmeyeceğini Nûreddin'e bildirerek 13 Eylül 1171 tarihinde Kahire'den hareket etti. Selâhaddin'den beklediği haberi alan Nureddin, Dımaşk'tan hareket ederek Kerek'e ulaştı; durup Selâhaddin'i bekledi. Ülkedeki karışıklıklar sebebiyle onun Kahire'ye dönmek zorunda kaldığını bildiren mektubunu aldı; ancak mazeretini kabul etmedi. Onun yakın adamları Nûreddin'e gitmemesi konusunda uyarmışlardı. Bu haber Nûreddin'e ulaşınca çok canı sıkıldı; Mısır'a yürümek istedi. Durumu öğrenen Selâhaddin, aile meclisini topladı; konuyu onlara açtı. Ortalı̆̆ sessizlik kapladı, yalnız yeğeni Takiyyüddin Ömer, gelirse savaşır ve Mısır'dan kovarız, deyince, diğer aile bireyleri onun görüşüne katıldı. ileri görüş, plan ve akıllılı̆̆yla bilinen Necmeddin Eyyûb, şiddetle bu görüşe karşı çıkarak yeğenini kınadı ve Selâhaddin'e dönüp şöyle söyledi: “ Ben baban, şu da dayın Şihabüddin, sen buradaki herkesin seni sevdiğini ve iyiliğini istediğini mi sanıyorsun? Vallahi, ben ve dayın, Nûreddin'i görsek koşup önünde yer öperiz, şayet senin boynunu vurmamızı istese, tereddütsüz dediğini yaparız. Biz böyle olursak diğer emirler onu görünce koşup önünde yerleri öpmekten başka ne yapabilir! Asker ve komutanlardan kim ona karşı çımaya cesaret edebilir? Bu memleketler onun, seni burada bulunduran da odur. Şayet seni görevden almak isterse buraya gelmesine ne gerek var; iki satırlık bir mektupla seni görevden alır ve dilediğini görevlendirir" diyerek, oradakilere dönüp: " kalkın, burayı terk edin, bizler Nûreddin'in memlûk ve kullarıyız, bize dilediğini yapar” dedi. Böylece topluluk dağıldı; orada olup bitenleri Nûreddin'e ulaştırdılar. Necmeddin oğlu Selâhaddin ile yalnız kalınca ona "Sen cahilsin, bilgin yetersiz, bütün bu insanları toplayıp gönlündekilerini onlara açıorsun, oysa Nûreddin senin kendisini Mısır'a sokmak istemediğini duysa, her işi bir yana bırakır, senin üzerine yürür, yürüdüğü zaman şu askerlerden hiç birini yanında göremezsin. Şimdi hemen kendisine bir mektup yazarak benim söylediklerimi bildir ve de ki: "Buraya gelmeye ne gerek var; bir görevliniz bana ipi getirir ve boynuma dolandırır. O bu sözleri duyunca seni bırakır, diğer işleriyle uğraşır". Nitekim olaylar Necmeddin'in dediği gibi gelişti. Nûreddin Mısır'a hareket etmedi ve öldü. Onun düşüncesi, ileri görüşlülüğün en mükemmel ve parlak örneği olmuştur". (ibni'l-Esîr 1963: 158-159)

Bazı araştırmacılar yukarıda ibni'l-Es'ir'in naklettiği sözleri ileri sürerek baştan beri Nûreddin'in Mısır'da yönetimin başında Selâhaddin'in olmasına karşı çıktığını söylerlerken, Selâhaddin'in de Nûreddin'e karşı gizli hesaplar içinde olduğunu ileri sürerler. (Beyyûmî 2005: 175) Oysa Nûreddin'in baştan beri Eyyûbî ailesiyle ilişkileri karşılıklı dostluk ve güven içerisinde yürümüş, Nûreddin'in takındığı tutum ve icraatlar yukarıdaki iddianın aksine bir seyir izlemiştir. En son olarak babası Necmeddin'i Mısır'a gönderirken Haçlılardan bir zarar gelmesin diye ortaya koyduğu gayret ve fedakârlıklar, Selâhaddin'e 
$404^{* \text { TAED }} 48$ Osman GÜRBÜZ

gönderdiği hediye ve armağanlar yukarıda anlatılmıştı. (Bkz. s.17-18) Ancak Nûreddin cihad masraflarının bir kısmını karșılamak için Selâhaddin'den altın göndermesini beklemekteydi; ne var ki Selâhaddin hem çok yoğun hem de vergilerin toplanmasında bazı sıkıntıları vardı. Mısırdan toplanan para ve altınların büyük kısmını daha önceden Dımaşk'a göndermiş, fakat Nûreddin gönderilen miktarı az bulmuştu. Bu yüzden gelirleri denetlemesi için Mısır'a bir müfettiş gönderilmiş, bu da Selâhaddin'in canını sıkmıştı. (Şeşen 1987: 61)

iki kadim dost, iki yiğit mücahid arasında bazı serinlikler, küçük sıkıntılar yaşansa da Nûreddin ve Selâhaddin asla, bazı tarihçi ve araştırmacıların iddia ettiği gibi birbirlerini kollayan iki sinsi hasım (ibni Vâsıl 1957: 1/259) konumuna düşmemişlerdir. Nûreddin'in ölümüne kadar Selâhaddin yapacağı işlerde onun onayını almış, Libya, Yemen, Nûbe seferlerini ancak ondan izin alarak başlatmıştı. Diğer yandan Selâhaddin ölümünden sonra Nûreddin'i hep rahmetle anmış, ondan bahsederken "Efendim, Nûreddin" diyerek kendisininden söz etmiş, Nûreddin'in ölümü üzerine bağlı melikler bağımsızlıklarını ilan ettikleri halde Selâhaddin efendisinin küçük oğlu adına para bastırmış, hutbe okutmuştu. (Şeşen 1987: 61)

\section{Sonuç}

Selâhaddin'in Kürt asıllı olduğu hususunda, bir iki tarihçi dışında itiraz eden olmamıştır. Ne var ki onun ve ailesinin Selçuklu komutan ve devlet adamlarının himaye ve desteğinde yetiştikleri de kimsenin inkâr etmediği bir hakikattir. İmâdüddin Zengî ve Nureddin Mahmud'un çabaları olmaksızın Selâhaddin'i düşünmek imkânsız gibidir. Selâhaddin, Zengîler'in sağlamış olduğu siyasi birlik ve Haçlılar'la cihat zemini üzerinde mücadelesini sürdürmüş ve seleflerinin dikmiş olduğu bayrağı yeni ufuklara ulaştırmaya muvaffak olmuştur. Onun mücadele aşkı ve şahsiyeti, insanımıza çok değerli ve zengin bir birikim sunmaktadır.

569/1174 yılında Nûreddin Mahmud Zengî öldükten sonra yerine on bir yaşındaki oğlu ìsmail geçti. Onun ölümüyle Suriye bölgesinde taht kavgaları artarak devam etti. Nûreddin yanlısı komutanların kendisini davet etmesi üzerine Suriye'ye hareket eden Selâhaddin Eyyûbî, kısa zamanda ülkenin büyük bölümünde siyasî birliği yeniden kurmayı başardı. 12 Şevval 570/6 Mayıs 1175 tarihinde Abbâsî halifesinin Suriye, Mısır ve el-Cezîre üzerinde Selâhaddin'in hâkimiyetini tanıyan taklidi (halifelik beratı) gelince Zengîler hanedanı yerini Eyyûbilere bırakmış oldu. Selçuklu-Fatımî devlet kurumlarına bazı düzenlemeler eklenerek oluşturulan yönetim sistemi, genel çizgileriyle Memlûkler Devleti'nin sonuna kadar devam etti. (Şeşen 1995: XII/21-24) 
iktidara Uzanan Yolda Eyyûbî Ailesinin Serüveni

${ }^{\text {TAED }} 48^{*} 405$

\section{KAYNAKÇA}

ALPTEKiN, Coşkun. “Musul Atabegliğg”, Doğuştan Günümüze Büyük İslâm Tarihi. İstanbul: Çağ yayınları. C. V, 1992.

BECKER, C. H. "Eyyûbîler", M.E.B. İslâm Ansiklopedisi. İstanbul: Milli Eğitim Basımevi. C. IV, 1979, s. 424-429.

BEYYUMî, Ali. Kuruluş Devrinde Eyyubîler, (Çev. Abdulhadi Timurtaş). i̇stanbul 2005.

Ed-DEVADÂRî, Aybek Ebu Bekr b. Abdillah. Kenzu'd-Durer ve Cami'u'l-Ğurer, (Thk. Abdulfettah Aşur), Kahire 1972.

EBÛ ŞÂME, Şihabuddin Abdirrahman b. İsmail, Kitabu'r-Ravdateyni fi Ahbari Devleteyni enNuriyyeti ve's-Salahiyyeti, (Notlar ve açıklamalar: ibrahim Şemsi). Beyrut: Daru'l-Kutubi'lilmiyye, C.I-V, 2002.

HiTTi, Philip K. Siyasî ve Kültürel İslâm Tarihi, (Çev. Salih Tuğ). İstanbul: IFAV yay., C. III-IV, 1995.

IBNi'L-ESîR, İzzeddin Ebu'l-Hasan Ali b. Muhammed b. Abdulvahid. et-Târîhu'l-Bâhir fi'dDevleti'l-Atabekiyye, (thk. Abdulkadir Ahmed Tuleymat). Kahire: Daru'l-Kütübi'l-Hadîse, 1963.

iBNi'L-ESîR, İzzeddin Ebu'l-Hasan Ali b. Muhammed b. Abdulvahid. el-Kâmil fi't-Târîh. Beyrut: Daru Sadr, ty.

IBNi HALDÛN, Ebu Zeyd Abdurrahman b. Muhammed. el- iber ve Dîvânu'l-Mübteda ve'l-Haber, (nşr. Ebu Suheybi'l-Kurmî). Riyad: Beytü'l-Efkâr, ty.

iBNi HALLiKAN, Ebu'l-Abbâs Şemseddin Ahmed. Vefayâtü'l-A'yân ve Enbâu Ebnâi'z-Zemân, (thk. ihsan Abbas). Beyrut 1977.

iBNi ŞEDDÂD, Bahâüddin. en-Nevâdiru's-Sultâniyye ve'l-Mehâsinu'l-Yûsufiyye, (thk.Cemâleddin Şeyyâl). Kahire: Mektebetu'l-Hancî, 1994.

iBNi VÂSIL, Cemaleddin Muhammed. Müferricül-Kürûb fi Ahbâr-ı Beni Eyyûb, (thk. A. Şeyyal). Kahire 1957, C.I-III.

KÖK, Bahaeddin. Nûruddin Mahmud Bin Zengî ve İslâm Kurumlar Tarihindeki Yeri, İstanbul: işsaret Yayınları, 1992.

MUSTAFA, Şakir. Salâhaddin. Dımaşk: Daru'l-Kalem, 1998.

ES-SALLABî, Ali Muhammed. ed-Devletü'z-Zengiyye. Beyrut: Daru'l- Ma'rife, 2007.

SOBERNHEiM, M. "Salâhaddin Eyyûbî̀", M.E.B. İslâm Ansiklopedisi. İstanbul 1979, 103-110.

ŞEŞEN, Ramazan. Salahaddin Eyyubi ve Devlet. İstanbul: Çağ yayınları, 1987.

ŞEŞEN, Ramazan. "Eyyûbîler", DiA. i̇stanbul, C. XII, 1995, 20-31. 